\title{
Recenzje
}

\section{WOKÓŁ SERBSKIEJ FANTASTYKI}

\author{
Krystyna Pieniaż̇eK-Marković ${ }^{1}$ \\ (Uniwersytet im. Adama Mickiewicza w Poznaniu)
}

Ewa Stawczyk. Z imaginarium fantastyki. Liryczno-oniryczny model serbskiej prozy postmodernistycznej. Gdańsk: Wydawnictwo Uniwersytetu Gdańskiego, 2016. 226 S.

Ewa Stawczyk przedmiotem zainteresowania $\mathrm{w}$ swej monografii uczyniła wybrany model prozy fantastycznej serbskiego postmodernizmu, który, dokonując kompilacji dotąd wypracowanych określen, nazwała liryczno-onirycznym, widząc $\mathrm{w}$ tej nazwie szansę na odzwierciedlenie dominujących $\mathrm{w}$ modelu strategii artystycznych. Traktując ten rodzaj twórczości za całość zamkniętą, aktualnie nieznajdującą swoich kontynuatorów, stworzyła zatem cenną monografię wybranego zjawiska. Nie oznacza to, że szczegółowej analizie poddała każdy tekst realizujący wyznaczniki modelu. Formułując warunki, które są niezbędne, by włączyć dany utwór do omawianego typu prozy fantastycznej (postmodernizm, oniryczność, liryzm), autorka uznała - i swój wybór przekonująco uzasadniła - że spełnia je twórczość jedynie dwóch pisarzy: najbardziej znanego i cenionego w świecie,

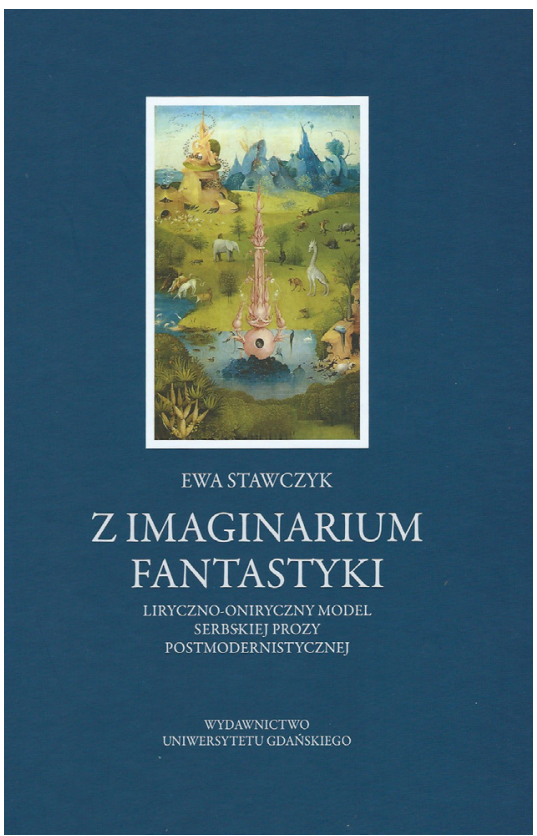
głównie dzięki powieści Słownik chazarski, przedstawiciela serbskiego postmodernizmu, Milorada Pavicia, oraz Gorana Petrovicia, jednocześnie kontynuatora i innowatora modelu Paviciowskiego.

Z niezwykle bogatej spuścizny Pavicia (ok. 50 pozycji) do analizy zostały wybrane tylko najbardziej znaczące powieści konceptualne (Hazarski rečnik, Zvezdani

1 E-mail: krypien@amu.edu.pl 
plašt, Predeo slikan čajem, Unutašnja strana vjetra, Poslednja ljubav u Carigradu), stanowiące - zdaniem Stawczyk - korpus wystarczający do zilustrowania tego, co charakterystyczne dla utworów wpisujących się w omawiany nurt. Dorobek Petrovicia także nie został zaprezentowany w całości, uwzględniono tylko te pozycje, które stanowią realizację modelu liryczno-onirycznego (Atlas opisan nebom, Sve što znam o vremenu. Izabrana kratka proza, Opsada crkve Sv. Spasa, Sitničarnica "Kod srećne ruke”). Taka decyzja autorki, dotycząca doboru tekstów, nie budzi zastrzeżeń. Można już na wstępie dodać, że analityczno-interpretacyjne rozdziały rozprawy, omawiające twórczość Pavicia i Petrovicia, stanowią jej najcenniejszy element, pokazują wrażliwość czytelniczą i demonstrują sprawność badawczą, przynosząc fragmenty na tyle ciekawe i inspirujące, że rozbudzają apetyt na kolejne. $Z$ tego punktu widzenia żal, że do rozprawy (i modelu) nie włączono twórczości innych pisarzy, choćby wspomnianego w monografii Nemanji Mitrovicia, który został odrzucony ze względu na zaliczenie jego dzieł do prozy poetyckiej. Można się zastanawiać, czy jest to kryterium dyswalifikujące, jeżeli nadal mamy prozę, liryczność, oniryczność i postmodernizm.

Na strukturę książki składają się wstęp, cztery rozdziały (teoretycznoliteracki, historycznoliteracki i dwa analityczne), zakończenie (właściwie Zamiast zakończenia), bibliografia, indeks osób oraz streszczenia w języku serbskim i angielskim. Zgodnie z oczekiwaniami, we wstępie autorka dąży do wyznaczenia zakresu i celu rozprawy i do wyjaśnienia pojęcia liryczno-oniryczny, przedstawia kryterium doboru autorów i tekstów oraz wykorzystane narzędzia interpretacyjne (psychoanaliza, fenomenologia, dekonstrukcjonizm, pragmatyzm, narratologia). Wychodzi od rozważań na temat oniryczności, skomplikowanych relacji i podobieństw między elementami wieloczłonowego szeregu tworzonego przez sen, literaturę, narrację, fikcję, fantastykę, oraz stawia tezę o istnieniu w ramach serbskiej prozy fantastycznej postmodernistycznego modelu liryczno-onirycznego.

Rozdział pierwszy $W$ poszukiwaniu definicji fantastyki zmierza do wyłonienia obowiązującego w rozprawie rozumienia fantastyki. Wykazując się znakomitą znajomością właściwej literatury przedmiotowej, Autorka śledzi wypowiedzi badaczy polskich, serbskich i światowych, a na ich podstawie stara się dać odpowiedź na pytanie o istotę literatury fantastycznej i fantastyczności. $W$ tym celu dąży do precyzyjnego oddzielenia od fantastyki takich pojęć jak fikcja, literatura mimetyczna, abstrakcja, mit, baśn i bajka magiczna, fantasy, fikcja spekulatywna (w tym science fiction) oraz prezentuje wybrane teorie i koncepcje literatury fantastycznej. W efekcie dokonanej prezentacji przywołanych stanowisk wyłonione zostaje wiążące kryterium, które decyduje o włączeniu danego tekstu do grupy utworów fantastycznych: „termin literatura fantastyczna odnosi się do tych utworów, które oparte są na motywacji fantastycznej" (Stawczyk 30). To lapidarne stwierdzenie Autorka uzupełnia objaśnieniem, czym jest motywacja fantastyczna. 
Rozdział drugi Tradycje fantastyczne w prozie serbskiej jest swoistym minikompendium wiedzy na temat serbskiej literatury fantastycznej od jej początków do dzisiaj. Historia gatunku została podzielona na cztery okresy: 1. średniowiecze, 2. okres od połowy XVIII wieku do końca realizmu, 3. od schyłku wieku XIX do lat siedemdziesiątych/osiemdziesiątych wieku XX i 4. okres ostatni, trwający do dziś. Autorka nie tylko odtwarza stan wiedzy, ale także zajmuje własne stanowisko. Nie przychylając się do opinii serbskich badaczy, skłonnych w ramy fantastyki włączać teksty średniowieczne, przekonuje o braku w nich motywacji fantastycznej, zastępowanej cudownością, i proponuje (zwracając uwagę na konieczność uwzględnienia kontekstu kulturowego i historycznego) mówienie o „pseudofantastyce” w nadprzyrodzonym realizmie wieków średnich.

Omawiając kolejny okres historycznoliteracki, Stawczyk zwraca uwagę na dominację $\mathrm{w}$ tekstach elementów zaczerpniętych $\mathrm{z}$ folkloru. Nie wnosząc zastrzeżeń do samego wywodu, który dobrze ilustruje, że fantastyczność utworów tego czasu nie wynika wyłącznie z inspiracji ludową twórczością ustną, zastanawiam się nad trafnością tytułu podrozdziału, który w obecnym brzmieniu (Pierwsze kroki. Fantastyka w ramionach folkloru) sugeruje, że to literatura ustna będzie przedmiotem badań ze względu na swój fantastyczny charakter. Autorka pisze: „,jedynym miejscem rozwoju fantastyki, niejako jej formą przetrwalnikową, staje się twórczość ustna" (Stawczyk 39). Tymczasem twórczość ustna była przez stulecia po prostu jedyną formą przetrwania literatury w ogóle, natomiast w folklorze - powiem, korzystając z narzędzi i języka Autorki - brak motywacji fantastycznej. Świat przedstawiony utworów literatury ustnej jest światem rzeczywistym jego nadawcy (wykonawcy) i odbiorcy, a obecna w warstwach treści folkloru słownego fantastyka przez odbiorców (słuchaczy) percypowana jest jako swoista rzeczywistość realna. Jedność miejsca i czasu: werbalizacji, tworzenia, przekazu, odbioru i cenzury, a zatem fundamentalna różnica między literaturą ustną a "pisaną" (usmena/pisana knjižeonost), czyni słuchacza współuczestnikiem kreowanego w dziełach folkloru słownego świata przedstawionego (realnego, wykonawca i słuchacz nie przenoszą się przecież w przestrzenie fantastyczne czy oniryczne). Warto może sięgnąć po prace Henryki Czajki, która pisząc o warstwach treści literatury słownej w epice bohaterskiej, nie wyróżniła warstwy fantastycznej, a elementy przez badaczy definiowane jako fantastyczne z perspektywy literatury "pisanej” ulokowała w warstwach: baśniowej, obyczajowej, chrześcijańskiej, mitologicznej i historycznej.

Do ilustracji kolejnego okresu rozwoju literatury fantastycznej wybrane zostały utwory reprezentantów awangardy: Stanislava Vinavera, Rastka Petrovicia, Momčila Nastasijevicia, oraz pisarzy współczesnych: Filipa Davida, Danila Kiša i Borislava Pekicia. Jako konieczny kontekst dwudziestowiecznej serbskiej (wówczas jugosłowiańskiej) fantastyki pojawia się oczywiście twórczość Jorge Luisa Borgesa. Dzieje najnowsze literatury fantastycznej są właściwie sprowadzone do postmodernizmu. Ten fragment monografii oferuje zatem także swoiste résumé tego, co charaktery- 
zuje sam postmodernizm (w tym istotną rolę modelu fantastycznego), oraz wiedzę na temat odwołującej się do postmodernistycznych strategii i fantastyki twórczości Svetislava Basary, Savy Damjanova, Đorđe Pisareva, Milorada Pavicia. Autorka interesująco pokazuje funkcjonowanie fantastyki na różnych poziomach tekstów. Szerzej prezentując wybrane utwory wymienionych autorów, daje także cenne informacje na temat podobnych strategii zastosowanych przez innych prozaików. Skrupulatnie odnotowuje różnorodne odmiany postmodernistycznej fantastyki serbskiej oraz stosowane chwyty, dokumentując przy tym świetną znajomość literatury przedmiotowej.

Zastanowienie budzi jednak nieobecność w tym przeglądzie bogatej serbskiej spuścizny nadrealistycznej z jej dążeniem do uchwycenia wizji sennych, halucynacji, majaków itp. Będąc równocześnie przestrzenią gier semantycznych, językowych eksperymentów, oscylując między semiotyczną zabawą, abstrakcją a jasnym dyskursem, niezwykle intrygująca twórczość serbskich nadrealistów wydaje się niezbędnym kontekstem dla postmodernistycznego modelu liryczno-onirycznego. Jej nieobecność jest tym bardziej zaskakująca, że Autorka nawiązuje w pracy do nadrealistycznych postulatów i samego André Bretona, wskazuje na porównywalne zrównanie rzeczywistości marzeń sennych z rzeczywistością jawy u nadrealistów i Gorana Petrovicia (Stawczyk 191), surrealistycznie zniekształconą czasoprzestrzeń w utworach Pavicia (Stawczyk 107), surrealistyczny sposób modelowania rzeczywistości czy - po prostu - surrealizm utworów Pavicia (Stawczyk 141).

Dwa rozdziały analityczne są największym walorem i w nich przede wszystkim realizowany jest cel pracy. Rozdział trzeci Milorada Pavicia wewnętrzna strona snu rozpoczynają rozważania poświęcone ontologii snu, natomiast dwa dalsze podrozdziały dotyczą sennych czasoprzestrzeni oraz onirycznej epistemologii. Zdaniem Badaczki, sen staje się u Pavicia synonimem tego, co fantastyczne (Stawczyk 107). Sen jako motyw przewodni, poetyzację prozy oraz erudycyjność uznaje ona za wyróżniki twórczości Pavicia, która równocześnie tworzy ramy dla całego nurtu. $\mathrm{W}$ rozdziale zostaje wyłoniony bogaty zestaw strategii wiodących do oniryzacji czasu i przestrzeni na różnych poziomach narracji, świata przedstawionego, snów i jawy bohaterów. Ze szczególną wrażliwością autorka śledzi wielorakie koncepcje czasu (i wieczności) wykreowane przez Pavicia, traktującego czas jako elastyczne tworzywo wyjątkowo podatne na wytwarzanie jego zadziwiających form, które w swej obfitości i równoległości mogą się pojawiać („,dziać”) na kartach jednego utworu. Podobnie jest zresztą z przestrzenią. Oniryczne czasoprzestrzenie stają się drogą dotarcia do tajemnic (np. tajemnego pisma), Absolutu (sfery sacrum), Boga i demonów, prawdy czy języka. Z zainteresowaniem czyta się fragmenty książki odsłaniające detektywistyczne skłonności autorki, wyczulenie na strategie, zastosowane chwyty, zastawiane na czytelnika pułapki. Stawczyk, podejmując się analizy twórzości Pavicia, stanęła przed trudnym zadaniem - z którym poradziła sobie bardzo dobrze - zmierzenia się z materią wielokrotnie omawianą także na grun- 
cie polskim. Uczyniła to, jednej strony odwołując się do poczynionych już ustaleń, a z drugiej samodzielnie odkrywając te miejsca w jego twórczości, które składają się na pełny obraz wykreowanego przez Pavicia modelu.

Równie ciekawy jest rozdział czwarty Gorana Petrovicia alchemia snu, składający się, podobnie jak poprzedni, z trzech podrozdziałów, które koncentrują się wokół następujących zagadnień: Oniryczny kosmos. Molekuły jawy i sny, Pejzaże światów możliwych oraz Onirotwórstwo literackie. Język jako tworzywo snu. Zostaje w nim zarysowany swoisty rozwój modelu: od powieści opartych na schematach wypracowanych przez Pavicia do indywidualnych, nowatorskich realizacji. W tej części ważnym fundamentem są prace Carla Gustava Junga, pomocne zwłaszcza w kontekście rozważań o nieświadomości zbiorowej (kiedy Autorka pisze o śnie kolektywnym) czy archetypach (kiedy analizuje bohaterów - spersonalizowane sny ludzkości w opowiadaniu Ostrvo). Stawczyk śledzi różnorodne relacje między jawą a snem, prezentowanym u Petrovicia jako rzeczywistość równoległa do jawy lub jako stan lotny (Atlas opisan nebom), oraz stany graniczne pomiędzy snem i jawą. Opisuje podobieństwa w kreacji świata-snu i świata-tekstu/lektury oraz w ich szkatułkowej strukturze. Oczywiście konteksty interpretacyjne można by rozszerzać, na przykład interesujące mogłoby być zestawienie koncepcji Petrovicia, zakładającej, że język jest gwarantem istnienia człowieka, z wypowiedziami Jacquesa Lacana zwłaszcza na temat języka jako przynależnego do sfery symbolicznej (sfery kultury), która wyklucza ze sfery realnego. W rozdziale poświęconym Petroviciowi Stawczyk nie mogła liczyć na pomoc w postaci gotowych już opracowań i wynikających z nich możliwych ścieżek lektury. Największe wyzwanie pisarz postawił przed czytelnikami zwłaszcza w książce Opsada crkve Sv. Spasa, która - mimo że okrzyknięta została najlepszą pozycją - nie doczekała się gruntownych badań. Autorka rozprawy musiała zatem samodzielnie zmagać się z wymagającą materią i doskonale sobie z nią poradziła.

Uznając model oniryczno-liryczny, realizowany przez Pavicia i Petrovicia, za całość zamkniętą, Stawczyk powraca do nadrzędnej kategorii, jaką jest fantastyka, i w zakończeniu dokonuje prezentacji osiągnięć serbskiej literatury w tym zakresie od końca XX wieku do dzisiaj. Jest to okres wzrostu zainteresowania gatunkiem, kiedy powstaje nie tylko literatura, ale i specjalizujące się $\mathrm{w}$ fantastyce wydawnictwa. Autorka dąży do wyodrębnienia aktualnie popularnych modeli (fantastyka urbalter, model legendarny) oraz wskazuje na twórczość autora - jej zdaniem obecnie najciekawszej prozy fantastycznej, Zorana Živkovicia.

Zakończenie wraz z wstępnymi partiami pracy tworzą przemyślaną całość, która zarówno przynosi informacje na temat historii rozwoju gatunku, jak i opisuje stan bieżący. Kompozycja pracy jest zatem dwudzielna, z jednej strony obejmuje teoretyczno- i historycznoliteracki kompleks zagadnień dotyczących całokształtu serbskiej literatury fantastycznej (rozdział I i II), z drugiej zaś materiał interpretacyjny będący rezultatem szczegółowego oglądu wybranego modelu gatunku - lirycz- 
no-onirycznego, w którym Autorka zmierza do syntezy zjawiska jednostkowego (rozdział III i IV).

W kluczowych dla rozprawy rozdziałach Autorka, posiłkując się właściwym aparatem metodologicznym (zwłaszcza psychoanaliza, myśl postmodernistyczna, narratologia), dokonuje wnikliwej hermeneutycznej i heurystycznej lektury tekstu, głęboko wnika w poetykę niełatwych przecież w odbiorze postmodernistycznych gier i labiryntów. Wykazuje się przy tym zarówno sprawnością warsztatową, jak i niezbędną czytelniczą wrażliwością. Zaprezentowane interpretacje wybranego materiału oraz próby jego klasyfikacji są interesujące i przekonujące. 